УДК 631.4(571.54)

DOI:10.18101/2542-0623-2019-3-37-53

\title{
ПОЧВЕННО-РАСТИТЕЛЬНЫЙ ПОКРОВ БОЛОТ И ЗАБОЛОЧЕННЫХ ПОНИЖЕНИЙ В ЗОНЕ ВЛИЯНИЯ ТЕРМАЛЬНЫХ ПОЛЕЙ БАРГУЗИНСКОГО РИФТА
}

\section{В. Л. Убугунов, В. И., Убугунова, Ю. А. Рупышев, Н. Б. Хитров}

(C) Убугунов Василий Леонидович

кандидат биологических наук,

Институт общей и экспериментальной биологии СО РАН

Россия, 670047, г. Улан-Удэ, ул. Сахьяновой, 6

E-mail: ubugunovv@mail.ru

\section{(C) Убугунова Вера Ивановна}

доктор биологических наук, профессор,

Институт общей и экспериментальной биологии СО РАН

Россия, 670047, г. Улан-Удэ, ул. Сахьяновой, 6

E-mail: ubugunova@mail.ru

(C) Рупышев Юрий Алексеевич

кандидат биологических наук,

Институт общей и экспериментальной биологии СО РАН

Россия, 670047, г. Улан-Удэ, ул. Сахьяновой, 6

E-mail: rupyshev@mail.ru

\section{(C) Хитров Николай Борисович}

доктор сельскохозяйственных наук,

Почвенный институт им. В.В. Докучаева

Россия, 119017, г. Москва, Пыжевский пер., 7 стр. 2

E-mail: khitrovnb@gmail.com

В северной части Баргузинской котловины в пределах термального поля разгрузки Кучигерских гидротерм формируются болота и заболоченные понижения. Они имеют сложную пространственную организацию и различную конфигурацию микроповышений, выраженных в виде бугров, валов и кочек. Основным фактором формирования микрорельефа является процесс выдавливания минерального вещества из нижних слоев почв и подстилающих грунтов. В связи с этим почвенно-растительный покров заболоченных территорий имеет существенные отличия от «классических» аналогов. Произрастающие виды включают водно-болотные, луговые, галофитные и галотолерантные растения. Поверхностные слои имеют органический, органо-минеральный или минеральный состав. Органический состав верхней части почв характерен для тростниковых и пузырчатоосоковых болотистых лугов. В местах, где пульпа прорывает почвенные слои, достигая дневной поверхности, верхние горизонты имеют минеральный состав. Их образование связано с восходящим гидротермальным и газофлюидным давлением из сейсмически активных глубинных разломов. На минеральных микроповышениях произрастают галофитные полынные и ползунковые сообщества.

Ключевые слова: рифтовая зона; болота; диапир; почвы; растительность; рельеф. 


\section{Для цитирования}

Убугунов В. Л., Убугунова В. И., Рупышев Ю. А., Хитров Н. Б. Почвенно-растительный покров болот и заболоченных понижений в зоне влияния термальных полей Баргузинского рифта // Природа Внутренней Азии. Nature of Inner Asia. 2019. № 3(12). C. 37-53. DOI: 10.18101/2542-0623-2019-3-37-53

\section{Введение}

В тектонически активных зонах широко развиты эндогенные процессы. В основе их проявления лежит механизм пульсационной дегазации, выражающийся в периодических проявлениях вулканизма, магматизма, метаморфизма и рудообразования. Через выводные каналы происходит разгрузка тепловых, газовых, водных, минеральных потоков из глубоких слоев литосферы на земную поверхность [Татаринов и др., 2016]. Разжиженные (флюидизированные) массы (грязевулканические, гидровулканические и др.) с характерным для них взрывным типом разгрузки изменяют процессы седиментогенеза, формы рельефа [Лунина и др., 2009] и оказывают влияние на функционирование экосистем [Гольдфарб, 2005; Геохимическая... 2011; Самкова и др., 2016; Armstrong, 1995; Gwynn et al., 2016].

Для большинства рифтогенных систем мира (островных дуг, активных окраин андийского типа, зон сочленения континентов, участков аномального вулканизма в пределах срединно-океанических хребтов, аномального внутриплитового вулканизма) характерно проявление вулканических извержений в виде излияния магмы, выбросов пепла, раскаленных обломков. Для внутриконтинентального Байкальского рифта характерно отсутствие вулканических извержений в виде фонтанирования жидкого магматического расплава. В большинстве случаев в этом районе происходят газогидротермальные проявления и грязевулканические извержения [Исаев, 2001, 2016; Татаринов и др., 2016].

Цель работы - изучить влияние активных и скрытых разгружающихся флюидных потоков (Кучигерское термальное поле, Баргузинская котловина) на почвенно-растительный покров болотных массивов.

\section{Объекты и методика}

Исследования проводились в северной части Баргузинской котловины (рис. 1).

Эта часть котловины сейсмически активна и характеризуется максимальным тепловым потоком [Голубев, 2007; Лысак, 2002], густой сетью тектонических разломов [Лунина и др., 2009], областью проявления грязевого вулканизма [Татаринов и др., 2016], самопроизвольным выходом свободных газов [Исаев, 2006; Макаров, 2009] и разгрузкой термальных источников кульдурского типа [Чернявский и др., 2018].

Объект исследования - болотные и заболоченные массивы, расположенные в зоне активного (трансекта РФ-1) и опосредованного (трансекта РФ-2) влияния кучигерских гидротермальных источников. В настоящем сообщении использовали болотные и заболоченные участки геоморфологических трансект: РФ-1 一 точки РФ-1-8 и РФ-1-3; РФ-2 — точки РФ-2-11, РФ-2-12, РФ-2-16, РФ-2-18 и РФ-2-19. Почва и растительность изучались на болотах с активными высокотемператур- 
ными (РФ-1-8) и низкотемпературными грифонами (РФ-1-1), на периферийном участке болот на границе с валом-диапиром (РФ-1-11), на минеральных газогидротурбированных кочкарных болотах (РФ-2-12, РФ-2-16, РФ-2-18, РФ-2-19).
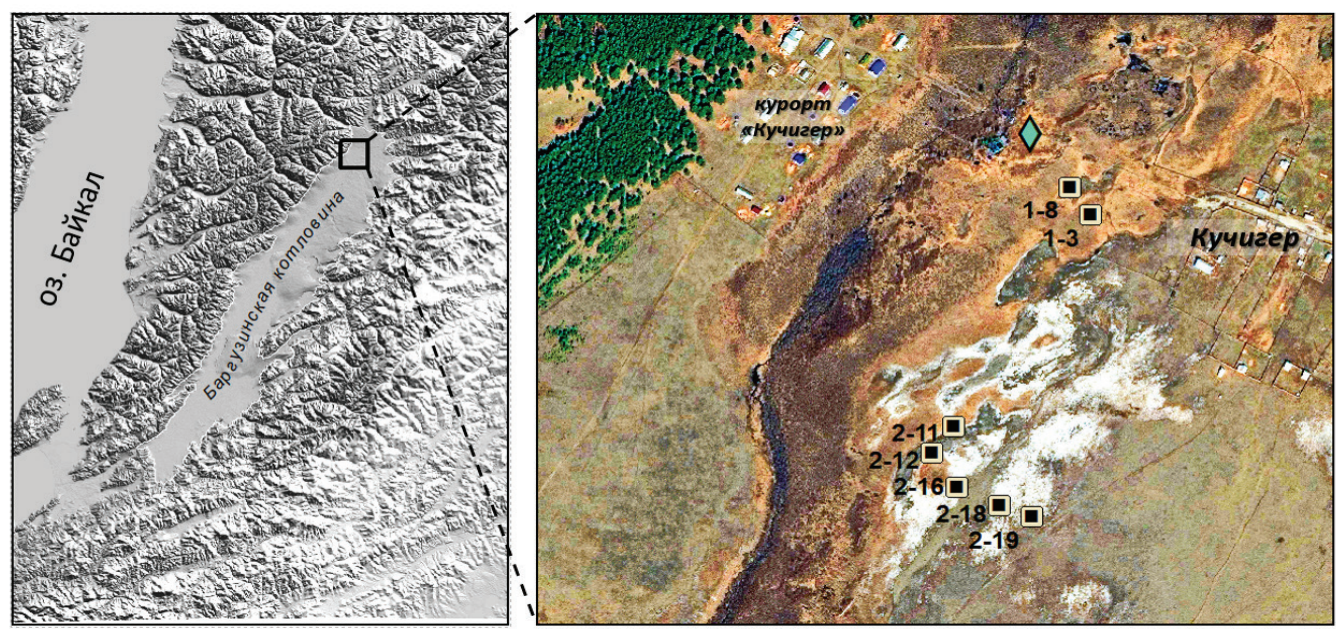

Puc. 1. Географическое положение площадок почвенно-ботанического обследования

Таблииа 1

Координаты точек обследования

\begin{tabular}{|c|c|c|}
\hline Трансект & Разрез & Координаты \\
\hline \multirow{2}{*}{ РФ-1 } & РФ-1-8 & 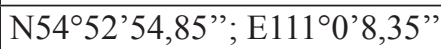 \\
\hline & РФ-1-3 & 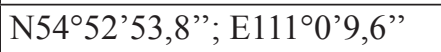 \\
\hline \multirow[t]{5}{*}{ РФ-2 } & РФ-2-11 & $\mathrm{N} 54^{\circ} 52^{\prime} 45,8^{\prime \prime} ; \mathrm{E} 111^{\circ} 0^{\prime} 1,2^{\prime \prime}$ \\
\hline & РФ-2-12 & N5452’44,8”; E11059'59,9”" \\
\hline & РФ-2-16 & 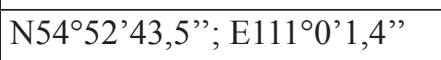 \\
\hline & РФ-2-18 & 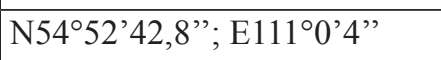 \\
\hline & РФ-2-19 & 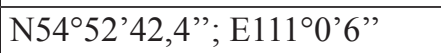 \\
\hline
\end{tabular}

Во время полевого этапа особое внимание уделяли морфологическому описанию почв. Проводились замеры температуры, $\mathrm{pH}$, определяли потерю органи-

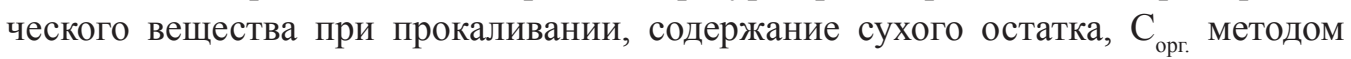
мокрого сжигания по Тюрину, гранулометрический состав методом Качинского [Агрохимические... 1975]. Диагностику почв выполняли по «Классификации почв России» [2004] и «Полевому определителю» [2008]. Ботанические исследования проводились методом конкретных (локальных) флор [Толмачев, 1974] в пределах урочища с использованием проб флоры окрестностей (географического) пункта [Юрцев, 1968]. Обработка материалов проводилась согласно [Методы... 2002]. Отнесение растений к экологическим группам по факторам влажности и засоленности давали в соответствии с работами Е. А. Клещевой [2010] и Б. Б. Найданова 
и др. [2010]. Анализ биоморф растений проведен в соответствии с классификацией И. Г. Серебрякова [1962; 1964]. Принадлежность к эколого-ценотическим комплексам, поясно-зональным группам определялась по Л. И. Малышеву, Г. А. Пешковой [1984].

\section{Результаты исследования}

Поверхность болот с активными грифонами (РФ-1-8) состоит из чередующихся выпуклых торфяных кочек (высота от 6-10 до 12-18 см) и вогнутых ячеек мочажин (от 25 до 40-45 см). В местах разгрузки гидротерм формируются достаточно крупные мочажины-озерца (диаметр от 1-2 до 5-10 м). Температура воды сравнительно постоянная $18-22{ }^{\circ} \mathrm{C}$. Состав воды близок к составу разгружающихся подземных термальных вод. Среди катионов доминирует натрий (более 90-95\%), среди анионов - гидрокарбонат-ион и сульфат-ион. На этом болотном массиве произрастают тростниковые болота (Phragmites australis) (рис. 2). Они включают всего 5 видов растений — доминирующий тростник южный и сопутствующее разнотравье, которые определяют обычный облик северных болот. В экологических группах преобладают гигрофиты, характеризующие данную экосистему как стабильную по водному режиму. Биоморфологический спектр представлен длинно- и короткокорневищными видами (табл. 2).

Таблищза 2

Характеристика болотных растительных сообществ гидротермального урочища «Кучигер»

(*ОПП - общее проективное покрытие)

\begin{tabular}{|c|c|c|c|c|c|c|c|c|}
\hline \multirow[b]{2}{*}{ № п/п } & \multirow[b]{2}{*}{ Сообщество } & \multirow[b]{2}{*}{ ОПП,\% } & \multirow[b]{2}{*}{ 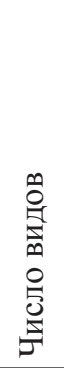 } & \multicolumn{4}{|c|}{ Состав } & \multirow[b]{2}{*}{ Доминанты } \\
\hline & & & & 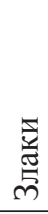 & $\begin{array}{l}0 \\
\stackrel{0}{0} \\
\tilde{0} \\
\stackrel{0}{0} \\
0\end{array}$ & $\begin{array}{l}0 \\
0 \\
0\end{array}$ & 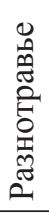 & \\
\hline РФ-1-8 & Тростниковое & 72 & 5 & 1 & - & & 4 & Phragmites australis \\
\hline РФ-1-3 & Тростниково-осоковое & 80 & 7 & 1 & - & 1 & 5 & $\begin{array}{l}\text { Phragmites australis } \\
\text { Carex enervis }\end{array}$ \\
\hline РФ-2-11 & Пузырчатоосоковое & 70 & 7 & 1 & - & 1 & 5 & Carex vesicaria \\
\hline РФ-2-16 & $\begin{array}{l}\text { Ползучеосоково- } \\
\text { ползунковое }\end{array}$ & 40 & 9 & 2 & & 1 & 6 & $\begin{array}{l}\text { Carex reptabunda, } \\
\text { Halerpestess alguinosa }\end{array}$ \\
\hline РФ-2-18 & Ползунковое & 20 & 7 & 1 & & 1 & 5 & Halerpestess alguinosa \\
\hline РФ-2-19 & Укрополистнополынное & 20 & 7 & 1 & & 1 & 5 & Artemisia anethifolia \\
\hline
\end{tabular}


В. Л. Убугунов, В. И. Убугунова, Ю. А. Рупышев, Н. Б. Хитров. Почвенно-растительный покров болот и заболоченных понижений в зоне влияния термальных полей Баргузинского рифта

РФ-1-8
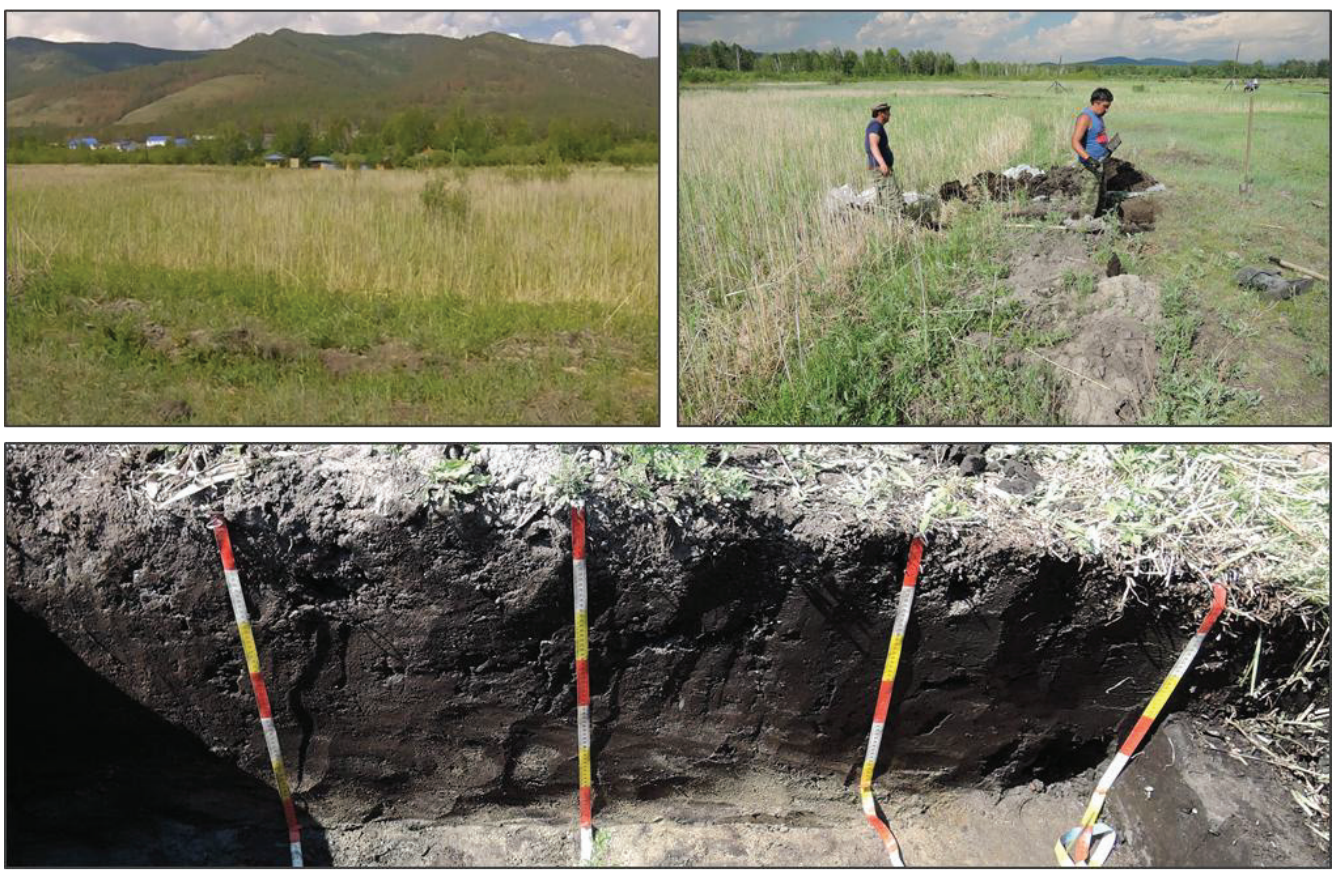

РФ-1-3
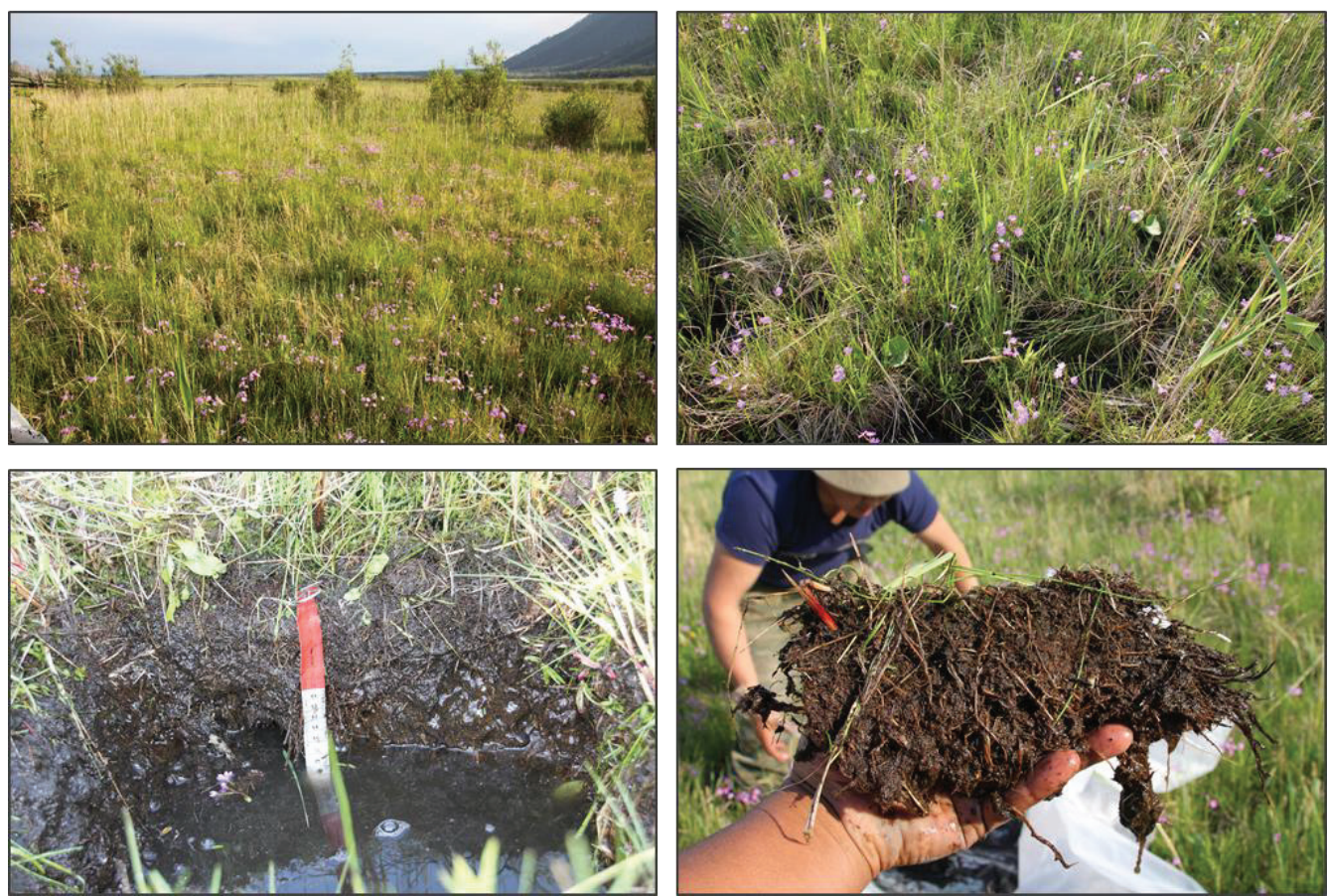

Puc. 2. Ландшафты и морфологическое строение профиля почв, формирующихся в зоне активной разгрузки высокотемпературных (РФ-1-8) и низкотемпературных (РФ-1-3) грифонов 
На болотном массиве с тростниковым сообществом болотные кочки органогенные, пронизаны живыми корневищами тростника южного (Phragmites australis) и/или осоки ползучей (Carex reptabunda), лапчатки гусиной (Potentilla anserina), а также других более редко встречающихся видов растений (табл. 2).

Формирующиеся под тростниковыми сообществами почвы имеют систему генетических горизонтов: TE (H)-G-CG. Такое строение профиля диагностирует тип аллювиальной торфяно-перегнойно-глеевой почвы. Это подтверждают и имеющиеся аналитические данные (табл. 3). Верхние органогенные горизонты характеризуются высоким содержанием полуразложившихся растительных остатков, имеют нейтральную реакцию среды (6,7) (табл. 3). Минеральная часть профиля представлена сизым глеевым горизонтом легкосуглинистого гранулометрического состава с низким содержанием органики. Горизонт С песчаный, не засолен, имеет нейтральную реакцию среды.

Таблица 3

Некоторые физико-химические свойства почв болотных массивов, формирующихся в зоне активной разгрузки Кучигерских термальных вод

\begin{tabular}{|c|c|c|c|c|c|}
\hline \multirow{2}{*}{ Горизонт } & \multirow{2}{*}{ Глубина, см } & \multirow{2}{*}{$\mathrm{pH}_{\text {водн. }}$} & Сухой остаток & $\mathrm{C}_{\text {орг. }}$ & Фракция 1-0,01 мм \\
\hline & & & \multicolumn{3}{|c|}{$\%$} \\
\hline \multicolumn{6}{|c|}{ РФ-1-8 Аллювиальная торфяно-перегнойно-глеевая импрегнированная почва } \\
\hline TE & $0-20$ & 6,7 & 0,298 & $37,86^{*}$ & Не опр. \\
\hline $\mathrm{H}$ & $20-27(30)$ & 6,2 & 0,430 & $13,36^{*}$ & 59 \\
\hline Gimp & $27(30)-40$ & 5,8 & 0,084 & 1,58 & 73 \\
\hline $\mathrm{C}$ & 59-71 & 6,9 & 0,044 & 0,18 & 92 \\
\hline \multicolumn{6}{|c|}{ РФ-1-3 Аллювиальная торфяно-перегнойно-глеевая почва } \\
\hline $\mathrm{TE}$ & $0-20$ & 7,2 & 0,222 & $69,72 *$ & \multirow{2}{*}{ Не опр. } \\
\hline TEs & $20-40$ & 7,1 & 0,502 & $45,12 *$ & \\
\hline \multirow[t]{3}{*}{ Qs } & $40-80$ & 8,0 & 0,490 & 6,24 & 83 \\
\hline & $90-120$ & 8,6 & 0,444 & 7,19 & 83 \\
\hline & $120-160$ & 9,2 & 0,454 & 4,71 & 85 \\
\hline Cs & $160-190$ & 8,9 & 0,814 & 4,31 & 85 \\
\hline
\end{tabular}

Второй участок болот с разгружающимися низкотемпературными грифонами расположен в 100-150 м от РФ-1-8. Вероятно, когда-то это был единый массив, но в результате активных тектонических процессов, происходящих в этом районе, образовался вал-диапир, который отделил часть болота (рис. 1). Поверхность кочковатая. Размеры кочек от 30-50 см в диаметре, 6-12 см по высоте. Между кочками расположены мочажинки с водой, которые являются местом разгрузки низкотемпературных грифонов. На этом участке было заложено 3 почвенно-растительных площадки. Для детального анализа рассмотрим РФ-1-3 с тростниково-осоковым сообществом. Оно насчитывает 7 видов растений с общим проективным покрытием 80\%. Преобладают луговые длинно- и коротко-корневищные растения, которые индуцируют все лугово-болотные эколого-ценотические комплексы исследу- 
емой территории. Практически равное участие гигридов и мезидов указывает на стабильность водного режима экосистемы. В растительном покрове доминирует Carex enervis, Potentilla anserina, Phragmites australis.

Изученные почвы имеют морфологический профиль: TE(H)-G-CG. Верхняя часть профиля почв представляет собой эутрофный торф (2,5Y 3/2) буроватого цвета, состоящий из растительных остатков (ППП 69,7 \%) различной степени разложенности, обильно пронизанных живыми корнями. Засоление отсутствует, реакция среды нейтральная. На глубине 13(20)-40 см отмечается некоторое снижение содержания органики $(45,1 \%)$, обнаружены редкие мелкие камешки и крупный булыжник диаметром около 10 см. Горизонт мокрый. На глубине 40-50 см 12 июня 2018 г. был обнаружен сезонно-мерзлый твердый минеральный горизонт черного цвета (GLEY1 2,5/N), содержащий белые кристаллики льда размером 1-3 мм. Изпод этого временного водоупорного горизонта поднималась грунтовая вода с температурой $0,1^{\circ} \mathrm{C}$, которая глубже постепенно повышалась до $+5,3^{\circ} \mathrm{C}(130-170 \mathrm{~cm})$. Ниже 50 см залегают неоднородно окрашенные сизые (Gley2 4/10B), темно-сизые (GLEY1 4/10GY) горизонты легкого гранулометрического состава. Глеевые слои имеют щелочную и сильнощелочную реакцию среды (pH 8,6-9.4), засолены, химизм засоления по анионам - сульфидный; по катионам — натриево-кальциевый (табл. 3).

Нами изучались также кочкообразные микроповышения как на периферийных участках основного болотного массива на границе с валом-диапиром (РФ-2-11), в заболоченных понижениях-сателлитах, отгороженных от основного болота валами (РФ-2-12; РФ-2-16), так и в изолированных переувлаженных просадках на прилегающей аллювиальной равнине (РФ-2-18, РФ-2-19). Периферийные участки сильно переувлажненных мест с высокими прибрежными валами-диапирами представляют собой цепочки микроповышений, которые в несколько рядов «опоясывают» контактную полосу с болотом (рис. 3). По своей форме чаще всего они похожи на тумбовидные образования с очень крутыми боковыми стенками и слегка закругленной выпуклой верхней стороной, хотя встречаются варианты конической формы с выпуклыми наружу сторонами конуса и сглаженной вершиной (рис. 3). Между цепочками микроповышений образовались микродолины, похожие на трещины разрыва, днище от 7-13 см до 60-67 см.

На этих участках произрастают пузырчатоосоковые (РФ-2-11) и дернистоосоковые (РФ-2-12) болотистые луга. По отношению к фактору влажности растения пузырчатоосоковых лугов преимущественно гигрофиты. В эколого-ценотической структуре этих сообществ доминируют луговые виды, отмечается присутствие водно-болотных растений. Отличительной особенностью биоморфологического спектра является равное участие длинно-, коротко- и стержнекорневых групп растений. В составе сообществ встречается 7 видов растений, основную роль играют виды гигрофитной природы - Carex vesicaria, Potentilla anserina.

На кочкарных дернистоосоковых болотистых лугах (РФ-2-12) произрастает 12 видов растений. Доминирующий вид - Carex cespitosa. Проективное покрытие этих лугов 80-90\%, высота травостоя до 60 см. Структура двухъярусная, обычные виды этих лугов - Agrostis mongolica, Poa pratensis, Carex coriophora, Carex bicolor, Eriophorum polystachyon, Equisetum arvense, Equisetum palustre, Rhinanthus aestivalis, Triglochin palustre, Trifolium repens, Vicia cracca. 
РФ-2-11
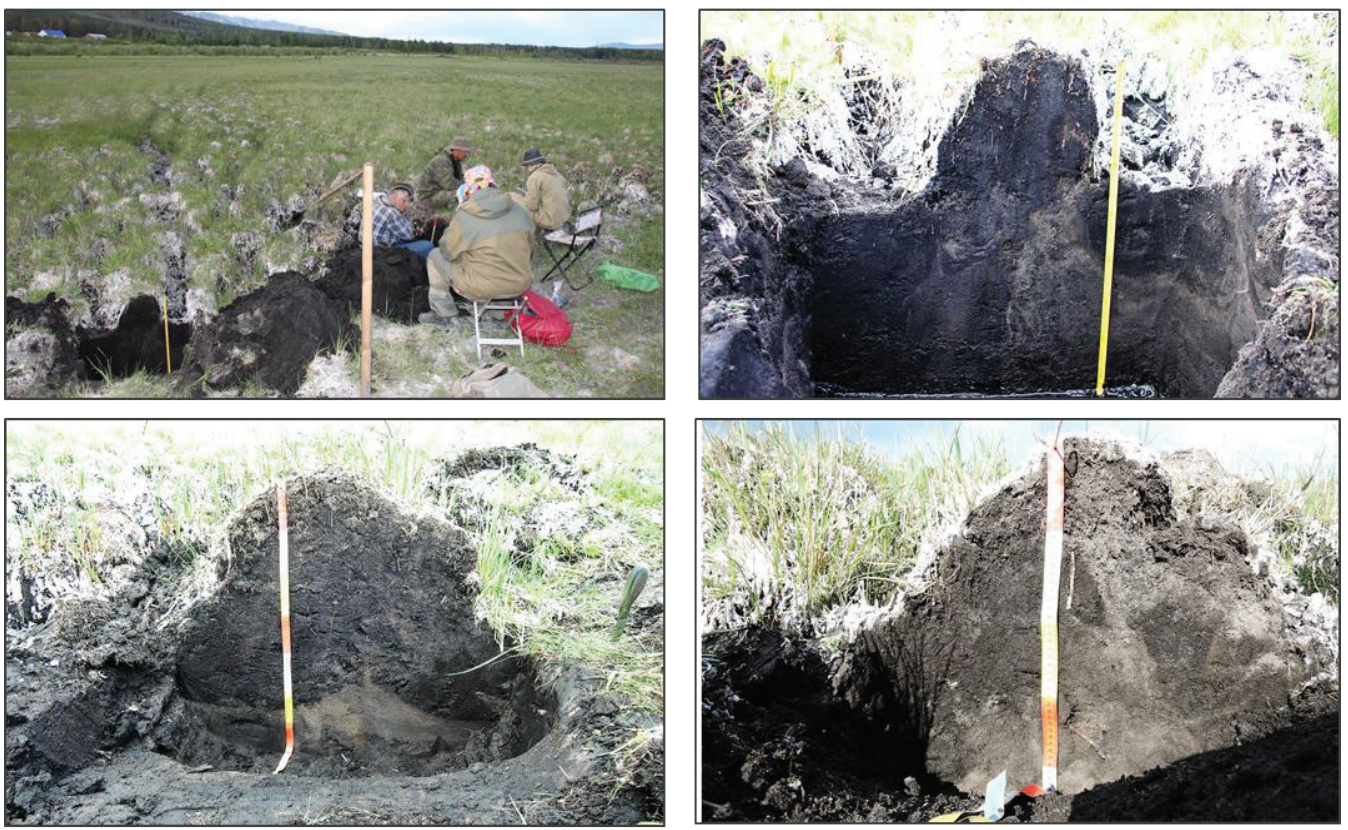

PФ-2-12
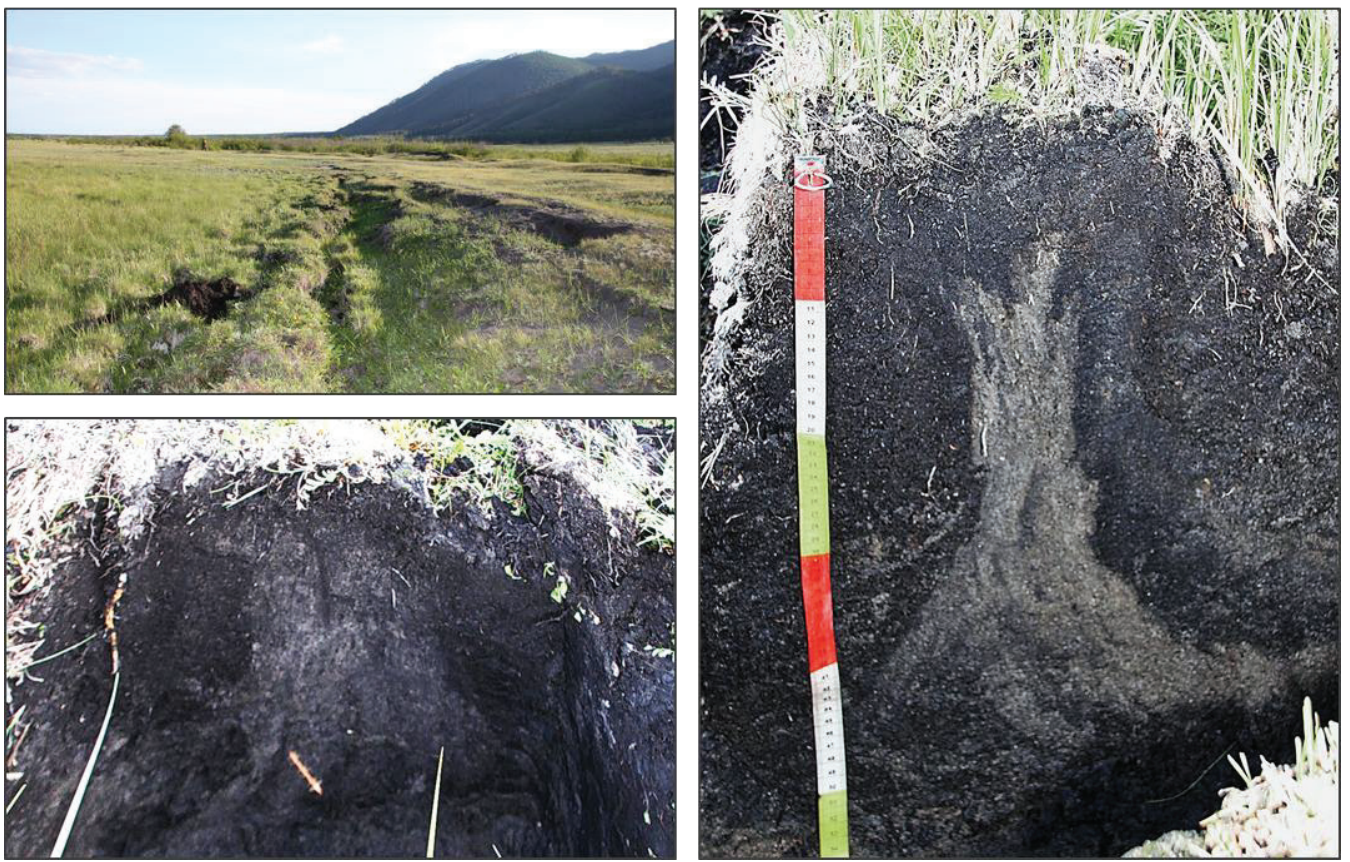

Puc. 3. Кочкообразные микроповышения периферийных участков болот (РФ-2-11; РФ-2-12) 
Поверхность кочек покрыта белыми выцветами солей. В ненарушенном строении почвы, формирующиеся в контактной зоне с болотами, как могут иметь морфологическое строение и физико-химические свойства, близкие с рассмотренными выше болотными почвами, так и могут заметно отличаться (рис. 3 ; табл. 4). Однотипное строение и свойства имеют почвы пузырчатоосоковых болотистых лугов. Верхняя часть профиля представлена преимущественно органогенной массой $(\mathrm{H})$. Потеря при прокаливании в 0-50 см слое варьирует от 24 до $40 \%$. Слой $0-5$ см сильно засолен $(3,788 \%)$. Реакция среды кислая $(4,8-4,9)$. Глубже содержание органической составляющей резко падает до $1-3 \%$. Гранулометрический состав минеральной части почвы характеризуется преобладанием песчаных фракций (табл. 4).

Внутреннее строение «кочкообразных» микроповышений, на котором произрастают дернистоосоковые луга, принципиально отличается от строения растительных кочек на болоте с пузырчатоосоковыми лугами. Они имеют минеральный состав. Для морфологического строения характерна выдавленность импрегнированной битумами вяжущей массы песчаного материала к дневной поверхности. Реакция среды кислая, слой засолен, содержание органического материала составляет в $0-9$ см слое всего $1,46 \%$.

Таблица 4

Некоторые физико-химические свойства почв периферийных участков болот (РФ-2-11, РФ-2-12)

\begin{tabular}{|c|c|c|c|c|c|}
\hline \multirow[t]{2}{*}{ Горизонт } & \multirow[t]{2}{*}{ Глубина, см } & \multirow[t]{2}{*}{$\mathrm{pH}_{\text {водн. }}$} & $\begin{array}{l}\text { Сухой } \\
\text { остаток }\end{array}$ & $\mathrm{C}_{\text {opr. }}$ & $\begin{array}{c}\text { Фракция } 1-0,01 \\
\text { мм }\end{array}$ \\
\hline & & & \multicolumn{3}{|c|}{$\%$} \\
\hline \multicolumn{6}{|c|}{ РФ-2-11. Аллювиальная перегнойно-глеевая импрегнированная засоленная } \\
\hline \multirow{4}{*}{ Hs } & $0,5-5$ & 4,8 & 3,788 & $33,85^{*}$ & \multirow{4}{*}{ Не опр. } \\
\hline & $5-20$ & 4,9 & 0,522 & $23,63 *$ & \\
\hline & $20-35$ & 4,7 & 0,678 & $23,71 *$ & \\
\hline & $35-50$ & 4,8 & 0,382 & $24,55^{*}$ & \\
\hline CG & $50-60$ & 4,4 & 0,170 & 0,25 & 97 \\
\hline IMPs & $70-78$ & 4,5 & 0,484 & 0,45 & 91 \\
\hline \multicolumn{6}{|c|}{ РФ-2-12. Аллювиальная турбированная засоленная } \\
\hline Aimp,s & $0-9$ & 5,3 & 0,886 & 1,46 & 81 \\
\hline Cs & $9-45$ & 4,9 & 0,718 & 0,42 & 94 \\
\hline
\end{tabular}

В просадках-сателлитах основного болотного массива, отделенных валами, микроповышения (РФ-2-16) имеют более плавные очертания по сравнению с тумбовидными аналогами непосредственно в зоне контакта болота с другим валом-диапиром (РФ-2-11 и РФ-2-12). Верхняя их часть слабовыпуклая с более сильно выраженной кривизной верхней границы вертикального сечения в поперечном направлении по сравнению с продольным. Верхушка плавно переходит в покатые неровные боковые поверхности. Относительная высота 
микроповышений этой группы (РФ-2-16) изменяется в пределах от 12 до 32 см, ширина — от 33 до 113 см, длина — от 50 до 240 см. На этом участке произрастают ползучеосоково-ползунковые сообщества. Проективное покрытие травостоя составляет всего 40\%. Фитоценоз представлен 9 видами. Доминанты - Carex reptabunda, Halerpestes salguinosa (рис. 4).

РФ-2-16
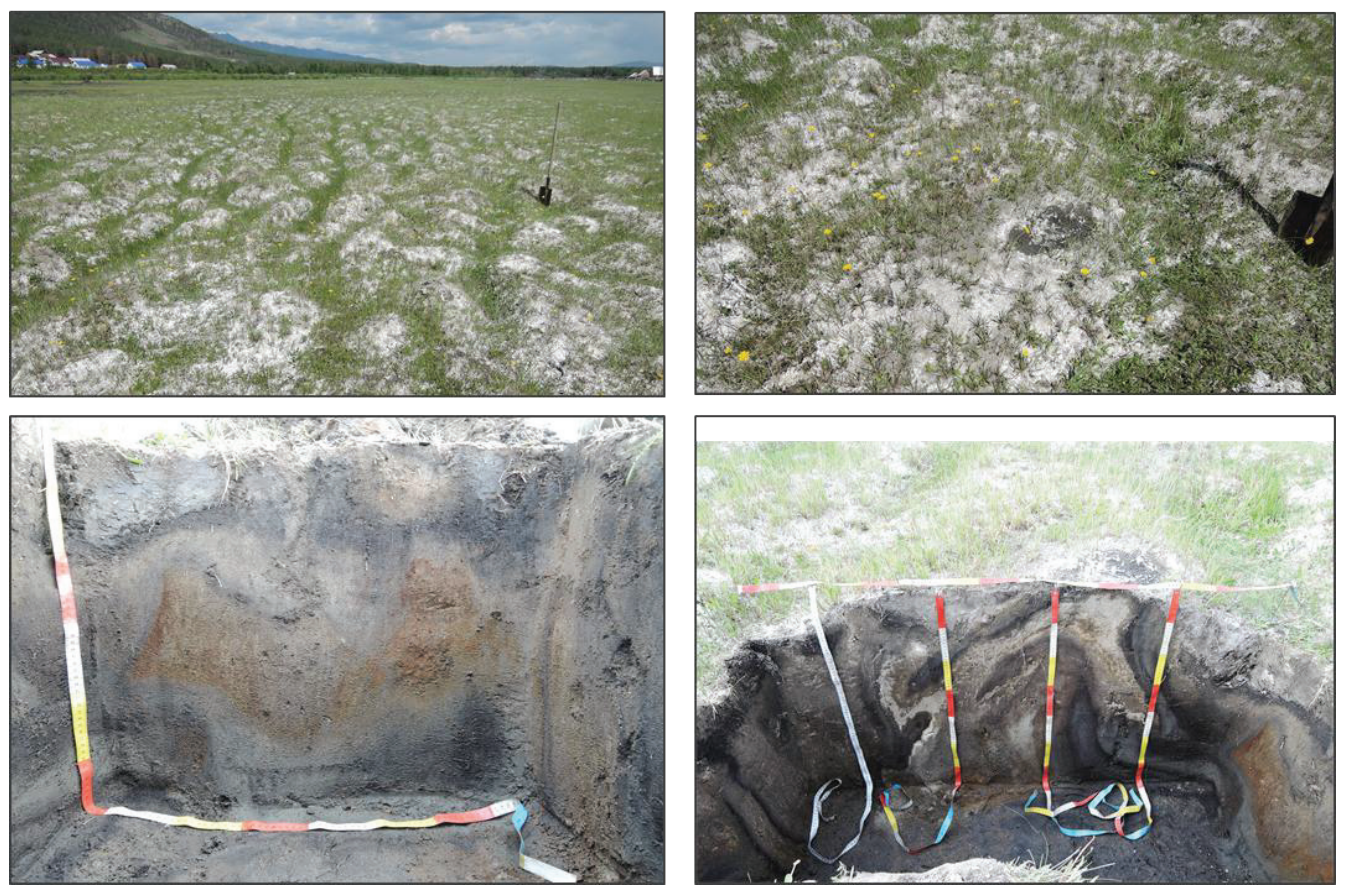

Рuc. 4. Рельеф, растительность и морфология почвенного профиля в пониженияхсателлитах, отделенных от основного болотного массива валами-диапирами (РФ-2-16)

Поверхность почвы на микроповышении и нижние части многих растений покрыты белыми выцветами легкорастворимых солей. Вертикальное сечение почвы показали, что они имеют очень сложное строение, не типичное для почв. Отмечается сильная турбированность профиля, отсутствие гумусово-перегнойного горизонта, присутствие песчаного, супесчаного и отчасти пылевато-суглинистого материала глеевого $(\mathrm{G})$ и квазиглеевого $(\mathrm{Q})$ горизонтов с разнообразным проявлением признаков импрегнирования (imp и IMP) и окисления. В восходящих языках различной конфигурации встречаются буро-черные морфоны с сильной пропиткой вяжущим битумоподобным веществом, либо вмещающая масса состоит из сизого материала глеевого горизонта. Такое морфологическое строение является закономерным результатом флюидного прорыва газов, вод и твердого материала на земную поверхность.

Глубина грунтовых вод на этом участке составила 75-80 см. Все морфоны, расположенные выше уровня грунтовых вод, имели кислую реакцию среды. $\mathrm{pH}_{\text {водн. }}$ варьировало от 4,7 до 6,1 , составляя в среднем 5,2 , содержание $\mathrm{C}_{\text {орг. }}$ изменялось от 0,2 до $0,7 \%$. Почва имела поверхностное засоление в солевой корке (табл. 5). 
В. Л. Убугунов, В. И. Убугунова, Ю. А. Рупышев, Н. Б. Хитров. Почвенно-растительный покров болот и заболоченных понижений в зоне влияния термальных полей Баргузинского рифта

Таблица 5

Некоторые физико-химические свойства почвенного профиля отшнурованного болотного массива (РФ-2-16)

\begin{tabular}{|c|c|c|c|c|c|}
\hline \multirow{2}{*}{ Горизонт } & \multirow{2}{*}{ Глубина, см } & \multirow{2}{*}{$\mathrm{pH}_{\text {водн. }}$} & $\begin{array}{c}\text { Сухой } \\
\text { остаток }\end{array}$ & $\mathrm{C}_{\text {орг. }}$ & Фракция 1-0,01 мм \\
\cline { 4 - 6 } & & \multicolumn{4}{|c|}{$\%$} \\
\hline \multicolumn{2}{|c|}{$\begin{array}{c}\text { Солевая } \\
\text { корка }\end{array}$} & $0-1$ & 4,7 & 0,950 & \multicolumn{2}{|c|}{ Не опр. } \\
\hline \multirow{2}{*}{$\mathrm{C}_{\text {ох }}$} & $1-7$ & 6,1 & 0,198 & 0,18 & 92 \\
\cline { 2 - 6 } & $7-13$ & 5,9 & 0,178 & 0,19 & 93 \\
\cline { 2 - 6 } & $13-20$ & 5,4 & 0,280 & 0,29 & 92 \\
\cline { 2 - 6 } & $20-40$ & 5,1 & 0,420 & 0,50 & 92 \\
\hline C & $40-65$ & 5,2 & 0,742 & 0,14 & 90 \\
\hline
\end{tabular}

Типовая принадлежность изученной «почвы» проблематична для определения. В профиле выделен 21 морфон. Современные процессы эндогенеза способствуют активной реседиментации вещества из нижележащих слоев, что находит отражение в морфологическом облике почвоподобных тел.

Юго-восточнее Кучигерского гидротермального поля на наклонной слабовогнутой поверхности аллювиальной равнины встречаются округлые или овальные пониженные участки с кочковатыми болотами. Поверхность их покрыта белой тонкой пухлой солевой корочкой (сульфат натрия). Микроповышения внутри таких поверхностей обычно имеют сглаженные формы как в вертикальном, так и в горизонтальном сечениях. Высота варьирует от 7 до 26 см, длина — от 52 до 250 см, ширина — от 32 до 188 см (рис. 5).

Растительность представлена ползунковым (РФ-2-18) и полынным (РФ-2-19) галофитным сообществами. Галофитный луг (Halerpestes salsuginosa) характеризуется низким проективным покрытием (20\%). Доминанты: Halerpestes salsuginosa, Potentilla anserina. Обилен Taraxacum dealbatum. Малочисленные виды: Chenopodium glaucum, Juncus compressus, Puccinellia hauptiana, Plantago salsa. В эколого-ценотической структуре преимущественно луговые растения. В биоморфологическом спектре доминирует группа короткокорневищных трав, для которых характерны жизненные стратегии с различными способами самоподдержания и адаптации к экстремальным условиям среды. По отношению к солевому фактору значительное участие играют галофитные и галотолерантные таксоны, а по отношению к влажности - мезофиты.

В галофитных полынных (Arthemisia anethifolia) лугах (РФ-2-19) присутствует 7 видов растений. Редкие разрозненные растения не образуют сплошного травяного покрова. Значительным участием отмечаются галофитные и галотолерантные травы. Фитоценозы образуют луговые, преимущественно азиатские виды. Биоморфологический спектр отличается практически равным участием различных групп - рыхло-, стержне- и короткокорневищной. 
РФ-2-18
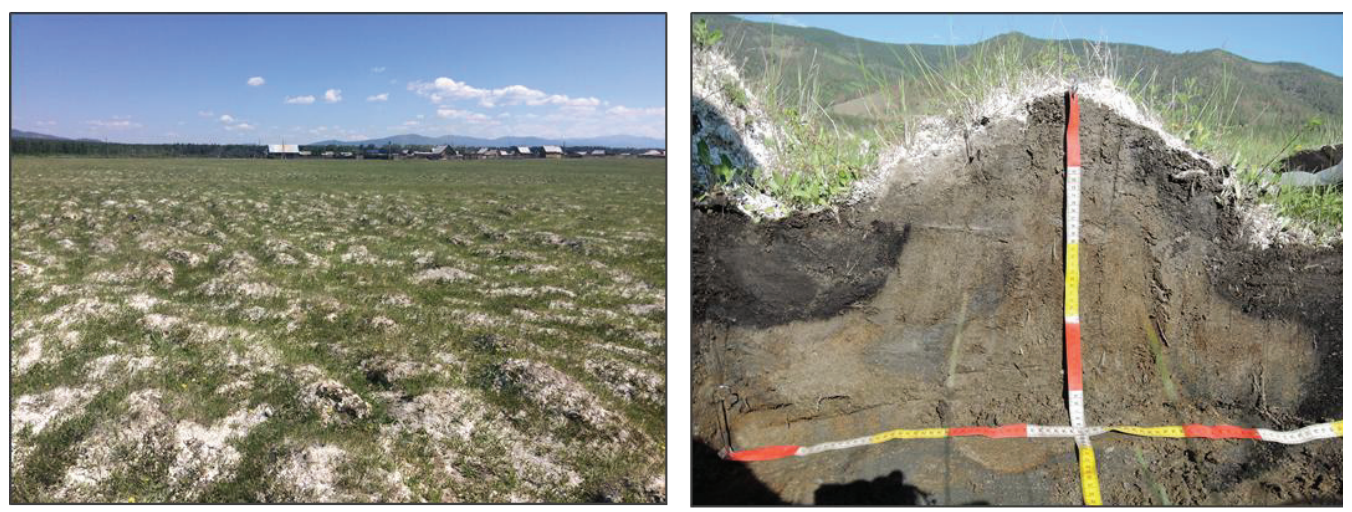

РФ-2-19
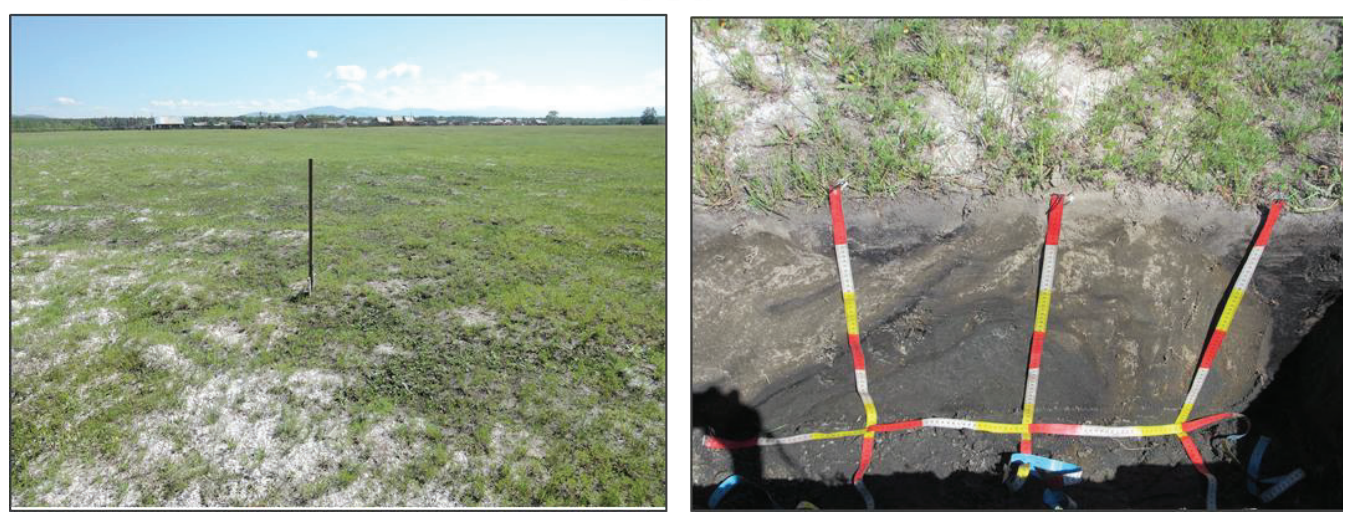

Puc. 5. Рельеф и морфология почвенного профиля овальных пониженных участков наклонной слабовогнутой аллювиальной равнины (РФ-2-18; РФ-2-19)

На поверхности кочкообразных повышений имеется солевая корочка. Строение «почвенного» профиля овальных понижений наклонной овальной равнины представляет собой выдавленную песчаную толщу (рис. 5). В изученных профилях отмечается влияние газотермального воздействия. Об этом свидетельствуют наклонные, вертикальные турбационные слои, в том числе и проявление импрегнации в виде тонких полосок или достаточно мощных слоев. Также выделяются зоны с частичным окислением восстановленных форм соединений железа в выдавленной снизу обводненной части, вероятно, глеевого горизонта.

Реакция среды изменяется от нейтральной до сильнощелочной. Нижняя часть профиля, расположенная ниже уровня грунтовой воды, сохраняет сильнощелочную реакцию среды ( $\mathrm{pH}>8,5)$, тогда как дренированная верхняя часть, в которой визуально наблюдаются зерна пирита, становится нейтральной или кислой $(\mathrm{pH}$ понижается до 5,4-6,8). Содержание $\mathrm{C}_{\text {орг. }}$ колеблется в пределах 0,34-0,84\%. Легкорастворимые соли аккумулируются возле поверхности в корке, а также отмечается их повышенное содержание в зоне выклинивания грунтовых вод. Близкое их расположение обеспечивает капиллярное подтягивание растворов к поверхности с образованием солевой корочки. 
В. Л. Убугунов, В. И. Убугунова, Ю. А. Рупышев, Н. Б. Хитров. Почвенно-растительный покров болот и заболоченных понижений в зоне влияния термальных полей Баргузинского рифта

На данном этапе исследований такие почвоподобные тела можно классифицировать как своеобразные турбоземы газогидротермальные окисленно-глеевые поверхностно-засоленные песчаные на аллювиальных отложениях.

Таблииа 6

Некоторые физико-химические свойства минеральных почв болотных массивов наклонной слабовогнутой поверхности аллювиальной равнины

\begin{tabular}{|c|c|c|c|c|c|}
\hline \multirow[t]{2}{*}{ Горизонт } & \multirow[t]{2}{*}{ Глубина, см } & \multirow{2}{*}{$\mathrm{pH}_{\text {водн. }}$} & $\begin{array}{c}\text { Сухой } \\
\text { остаток }\end{array}$ & $\mathrm{C}_{\text {opr }}$ & Фракция 1-0,01 мм \\
\hline & & & \multicolumn{3}{|c|}{$\%$} \\
\hline \multicolumn{6}{|c|}{ РФ-2-18 } \\
\hline С.к. & $0-0,5$ & 6,8 & & - & \multirow{2}{*}{ Не опр. } \\
\hline Cs & $0,5-5$ & 6,8 & 0,842 & 0,74 & \\
\hline \multirow{4}{*}{$\mathrm{C}$} & $5-15$ & 5,9 & 0,280 & 0,60 & 91 \\
\hline & $15-25$ & 5,6 & 0,189 & 0,05 & 91 \\
\hline & $25-40$ & 5,7 & 0,316 & 0,46 & 93 \\
\hline & $45-59$ & 6,4 & 0,354 & 0,34 & 94 \\
\hline \multirow{2}{*}{ Cs } & $59-65$ & 8,1 & 0,734 & 0,84 & 93 \\
\hline & $75-85$ & 9,1 & 0,500 & 0,53 & 93 \\
\hline \multicolumn{6}{|c|}{ PФ-2-19 } \\
\hline С.к. & $0-0,5$ & 9,1 & \multicolumn{2}{|c|}{ Не опр. } & \multirow{3}{*}{ Не опр. } \\
\hline \multirow{2}{*}{$\mathrm{C}$} & $0,5-4$ & 8,4 & \multirow{2}{*}{ Не опр. } & Не опр. & \\
\hline & $4-9$ & 8,0 & & 0,45 & \\
\hline \multirow{3}{*}{ Cimp } & $9-20$ & 6,6 & 0,484 & 0,57 & 92 \\
\hline & $22-30$ & 6,4 & 0,638 & 0,97 & 86 \\
\hline & $30-50$ & 8,0 & 0,614 & 0,81 & 90 \\
\hline
\end{tabular}

\section{Обсуждение}

Умеренные широты северного полушария, значительное преобладание территорий с горным рельефом и слабое распространение равнин являются факторами, препятствующими широкому распространению болотных экосистем в Забайкалье [Лбов и др., 2007]. Крупные массивы низинных болот с малой мощностью торфяных горизонтов встречаются только в тектонических впадинах кайнозойского возраста: Тункинской, Баргузинской, Верхнеангарской, процессы заболачивания в которых связаны с опусканием днища впадин [Петрович, 1965; Гынинова и др., 2012; Черкашина, Голубцов, 2016]. Причиной их заболачивания является относительно равнинный рельеф, застойное увлажнение или выклинивающиеся грунтовые воды и близкое подстилание многолетней мерзлоты. Ведущим биогенно-аккумулятивным процессом в болотных почвах является торфообразование, а метаморфическим - оглеение.

Наибольшей заторфованностью (13\%) и количеством заболоченных территорий характеризуется Баргузинская котловина [Лбов и др., 2007]. По имеющимся материалам эти массивы приурочены к днищам обсохших или пересыхающих озерных котловин и пониженным участкам пойм [Почвы... 1983; Убугунов В. Л. 
и др., 2016]. Болотные почвы этой территории характеризуются широким диапазоном варьирования свойств как органогенных, так и минеральных горизонтов: $\mathrm{pH}$ изменяется от нейтральной до сильнощелочной, содержание карбонатов от 0,6 до $7,3 \%$, в торфяном горизонте содержание органического вещества изменяется от 94,2 до $15,8 \%$, в верхнем минеральном горизонте - от 1,2 до $10,0 \%$, азота - от 0,05 до $0,70 \%$, емкость поглощения - от 2 до 27 мг.экв/100 г почв, плотный остаток от 0,19 до 0,36\% [Почвы... 1983; Убугунов Л. Л. и др., 2013;Убугунов В. Л. и др., 2016].

В северо-восточной части крыла Байкальской рифтовой зоны (северо-западная часть Баргузинской котловины) формирование почв происходит в условиях влияния тепловой аномалии, характерных только для областей активного вулканизма. На общем повышенном термическом фоне отмечается также вынос глубинного тепла с разгружающими термальными водами. Воздействие энергонесущих элементов глубинного строения Земли приводит к существенной модификации ведущих факторов формирования ландшафтов и формированию многообразных контрастных форм рельефа. На разнообразных микро- и наномикроповышениях с выраженными признаками засоления формируются необычные болота. Наряду с «классическими» болотными кочками (фитогенными, криогенными, зоогенными, скотобойными и др.), характерными для переувлажненных ландшафтов, встречаются приподнятые повышения, внешне напоминающие обычные болотные кочки, выстроенные в серию нескольких (до десятка и более) линий по окружности болот и заболоченных понижений. Кроме кочек, как в самих болотах, так и по берегам отмечали протяженные валы высотой от 0,2 до 1,0 и более метров, возникшие в результате деформации поверхности. Эти микроформы, несмотря на визуальное сходство, имеют принципиальные отличия от «классических» болотных кочек. При отсутствии подстилающей мерзлоты в зоне влияния гидротерм, а также по результатам изучения морфологии профиля кочек и валов криогенез, равно как и фито(зоо)генезис, поднятий, не подтвердился. Основным механизмом образования диапирового кочкарно-валистого рельефа переувлаженных позиций и их периферии в районе исследования является газогидротермально-флюидный, который приводит к пучению поверхности и вызывает кочковатость, бугристость, образование разнообразных валиков, валов, бугров пучения высотой от 0,2 до 4-5 и более метров высотой. Этот генезис подтверждают фактические данные морфологического облика поверхности, микроформ рельефа, вскрытых почвенных профилей. Они выражены в особенностях физических, физико-химических свойств, ботаническом составе растительности. Конфигурация сильно импрегнированных морфонов служит маркером зон формирования повышенного давления поднимающегося снизу материала и дальнейших путей перемещения материала при прорыве сдерживавшей кровли. Вертикальное расположение импрегнированных слоев является ярким свидетельством турбационного перемещения материала профиля бывшей гумусово-перегнойно-глеевой почвы с разрывом на фрагменты исходного горизонтального сплошного залегания слоев, локальным вспучиванием поверхности, приводящим к образованию микроповышения. Фрагменты горизонтов уложены в новый порядок в соответствии с величиной действовавших на них сил, их направлением, последовательностью и длительностью их действия во времени. 
Отличительной особенностью исследованной растительности является гетерогенность, возникающая в результате экотопических вариаций. Растительность дифференцируется на разном уровне от первичных группировок до разноразмерных галофитно-луговых и лугово-степных сочетаний и комбинаций. Моноценозы или сочетания из собственно галофитов Chenopodium glaucum, Suaeda glauca, S. corniculata формируются на интенсивно засоленных местообитаниях. На более сухих участках среди солонцеватых ячменных и ползучеосоковых лугов встречаются варианты с Artemisia anethifolia, S. amara, Plantago salsa. Значимое место занимают группировки с доминированием Potentilla anserina, Halerpestess alsuginosa, Taraxacum dealbatum, Glaux maritime на увлажненных территориях. Таким образом, неодинаковые условия по влажности и засоленности субстратов проявляются в комплексном характере растительного покрова, образующего флористически и физиономически различающиеся участки.

\section{Заключение}

Сложная пространственная организация и различная конфигурация микро- и наномикроповышений с выраженными признаками засоления на северо-западе Баргузинской котловины связана с восходящими потоками газогидротермальных флюидов из сейсмически активных глубинных разломов. В местах активной разгрузки термальных вод произрастают водно-болотные и луговые виды и формируются аллювиальные торфяно-перегнойно-глеевые почвы. В местах прорыва пульпы на дневную поверхность вскрытый профиль представляет собой сильно турбированное «почвоподобное» образование с разорванными фрагментами глеевого, и, возможно, гумусового горизонтов. На данном этапе исследований они диагностируют начальные стадии почвообразовательного процесса с про-явлением турбированности, импрегнирования, оглеения и засоления. В профиле отсутствуют характерные для почв горизонтальные слои, а морфологически выражены наклонные или вертикальные восходящие слои оглеенного аллювиального песка. На таких минеральных микроповышениях произрастают полынные и ползунковые галофитные сообщества.

Изучение необычных по генезису газогидротермальных болотных экосистем Байкальской рифтовой зоны находится на начальном этапе исследований. Необходимо проведение комплексных биологических исследований для оценки разнообразия и специфичности биоты на видовом, молекулярном и генетическом уровнях.

Работа выполнена при финансовой поддержке гранта РФФИ № 18-0400454 A om 15.02.2018.

\section{Литература}

Агрохимические методы исследования почв. М.: Наука, 1975. 656 с.

Геохимическая деятельность микроорганизмов гидротерм Байкальской рифтовой зоны / отв. редактор М. Б. Вайнштейн. Новосибирск: Гео, 2011. 302 с.

Голубев В. А. Кондуктивный и конвективный вынос тепла в Байкальской рифтовой зоне. Новосибирск: Гео, 2007. 222 с.

Гольдфарб И. Л. Влияние гидротермального процесса на почвообразование (на примере Камчатки): автореф. дис. ... канд. геогр. наук. М., 2005. 25 с. 
Гынинова А. Б., Шоба С. А., Балсанова А. Б., Гынинова Б. Д. Почвы дельты реки Селенги (генезис, география, геохимия). Улан-Удэ: Изд-во БНЦ СО РАН, 2012. 344 с.

Исаев В. П. Природные газы Баргузинской впадины. Иркутск: Изд-во ИГУ, 2006. 223 с.

Исаев В. П. Перспективы нефтегазоносности межгорных впадин Бурятии. Новосибирск: Гео, 2016. 165 c.

Классификация и диагностика почв России. Смоленск: Ойкумена, 2004. 342 с.

Клещева Е. А. Индикационные особенности растений юга Сибири по отношению к фактору увлажнения почвы. Экология. 2010. № 6. С. 425-431.

Лбов В. А. Убугунов Л. Л., Лбов А. В., Убугунова В. И. Агрономическое сырье Бурятии. Улан-Удэ: Изд-во БГСХА им. В. Р. Филиппова, 2007. 268 с.

Лунина О. В., Гладков А. С., Неведрова Н. Н. Рифтовые впадины Прибайкалья: тектоническое строение и история развития. Новосибирск: Гео, 2009. $316 \mathrm{c}$.

Лысак С. В. Тепловой поток в зонах активных разломов на юге Восточной Сибири // Геология и геофизика. 2002. Т. 43, № 8. С. 791-803.

Макаров М. М. Пузырьковые выходы метана из донных отложений озера Байкал: автореф. дис. ... канд. геогр. наук. Иркутск, 2009. 24 с.

Малышев Л. И., Пешкова Г. А. Особенности и генезис флоры Сибири (Предбайкалье и Забайкалье). Новосибирск: Наука, Сиб. отд-ние, 1984. 264 с.

Методы изучения лесных сообществ. СПб.: НИИХимии СПбГУ, 2002. 240 с.

Найданов Б. Б., Бадмаева Н. К., Аненхонов О. А., Пыхалова Т. Д. Галофитная растительность Западного Забайкалья: Флора и синтаксономия // Растительный мир Азиатской России. 2010. № 2 (6). С. 66-72.

Петрович П. И. Торфяные почвы дельты р. Селенги и их сельскохозяйственное использование. Улан-Удэ: Бур. кн. изд-во, 1965. 96 с.

Полевой определитель почв России. М.: Почвенный ин-т им. В. В. Докучаева, 2008. $182 \mathrm{c}$.

Почвы Баргузинской котловины. Новосибирск: Наука, Сиб. отд-ние, 1983. 270 с.

Самкова Т. Ю., Рылова С. А., Кляпицкий Е. С. Пространственная неоднородность термального поля и ее отражение в структуре растительного покрова юго-восточного участка Больше-Банного месторождения (Южная Камчатка) // Вестник Краунц. Науки о Земле. 2016. № 3, вып. 31. С. 18-27.

Серебряков И. Г. Жизненные формы высших растений и их изучение // Полевая геоботаника. М.; Л., 1964. Т. 3. С. 146-205.

Татаринов А. В., Яловик Л. И., Канакин С. В. Особенности формирования и минеральные ассоциации литокомплексов грязевых вулканов на юге Восточной Сибири // Вулканология и сейсмология. 2016. № 4.С.34-49.

Толмачев А. И. Введение в географию растений. Л. : Изд-во Ленингр. ун-та, 1974. $244 \mathrm{c}$.

Убугунов В. Л., Убугунова В. И., Цыремпилов Э. Г. Почвы и формы рельефа Баргузинской котловины. Улан-Удэ: Изд-во БНЦ СО РАН, 2016. 212 с.

Убугунов Л. Л., Хутакова С. В., Убугунова В. И. Разнообразие и основы рационального использования гидроморфных почв Байкальского региона. Улан-Удэ: Изд-во БГСХА им. В. Р. Филиппова, 2013. 148 с.

Черкашина А. А., Голубцов В. А. Структура почвенного покрова Тункинской котловины // География и природные ресурсы. 2016. № 3. С. 130-140.

Чернявский М. К., Плюснин А. М., Дорошкевич С. Г., Будаев Р. Ц. Рекреационно-бальнеологические особенности северо-восточной части Баргузинской котловины // География и природные ресурсы. 2018. № 2. С. 63-73.

Юрцев Б. А. Флора Сунтар-Хаята: проблемы истории высокогорных ландшафтов северо-востока Сибири. Л.: Наука, 1968. 235 с. 
В. Л. Убугунов, В. И. Убугунова, Ю. А. Рупьпшев, Н. Б. Хитров. Почвенно-растительный покров болот и заболоченных понижений в зоне влияния термальных полей Баргузинского рифта

Armstrong D. C. Acid Sulphate Alteration in a Magmatic Hydrothermal Environment, Barton Peninsula, King George Island, Antarctica // Mineralogical Magazine. 1995. September. V. 59. P. 429-441.

Gwynn M., Allis R., Hardwick C., Hill J., Moore J. A New Look at the Thermal Regime Around Roosevelt Hot Springs, Utah // GRC Transactions. 2016. V. 40. P. 551-558.

\title{
SOIL AND VEGETABLE COVER OF MARSHES AND MARSHY DEPRESSIONS IN THE AREA OF THERMAL FIELDS INFLUENCE IN BARGUZIN RIFT
}

\author{
V. L. Ubugunov, V. I., Ubugunova, Yu. A. Rupyshev, N. B. Khitrov \\ Vasiliy L. Ubugunov \\ Cand. Sci. (Biol.), \\ Institute of General and Experimental Biology SB RAS \\ 6 Sakhyanovoy St., Ulan-Ude 670037, Russia \\ E-mail: ubugunovv@mail.ru
}

Vera I. Ubugunova

Dr. Sci. (Biol.), Prof., Institute of General and Experimental Biology SB RAS

6 Sakhyanovoy St., Ulan-Ude 670037, Russia

E-mail: ubugunova@mail.ru

Yuriy A. Rupyshev

Cand. Sci. (Biol.),

Institute of General and Experimental Biology SB RAS

670047, Russia, Ulan-Ude, ul. 6 Sakhyanova,

e-mail: rupyshev@mail.ru

Nikolay B. Khitrov

Dr. Sci. (Agriculture),

Dokuchaev Soil Institute

Bldg 2, 7 Pyzhevsky Court, Moscow 119017, Russia

E-mail: khitrovnb@gmail.com

In the northern part of Barguzin Basin, marshes and marshy depressions are formed within the thermal discharge field of Kuchiger thermal springs. They have a complex spatial organization and various configurations of micro-elevations in the form of paps, embankmens and knolls. The main factor in formation of the microrelief is the extrusion of mineral substance from the lower layers of soils and underlying soils. In this regard, the soil and vegetation cover of wetlands has significant differences from the "classical" ones. Native species include wetland, meadow, halophytic and halotolerant plants. The surface layers have an organic, organo-mineral or mineral composition. The organic composition of the upper part of the soils is characteristic of reed and sedgy marshy meadows. In places where the pulp breaks through the soil layers, reaching the daylight surface, the upper horizons have a mineral composition. Their formation is associated with ascending hydrothermal and gas-fluid pressure from seismically active deep faults. Halophytic Artemisia anethifolia and Halerpestess alguinosa cenosis grow on mineral microelevations.

Keywords: rift zone; marshes; diapir; soils; vegetation; terrain. 